\title{
The State of Research on the Manichaean Bishop Faustus
}

\begin{tabular}{|c|c|}
\hline \multicolumn{2}{|c|}{$\begin{array}{l}\text { Author: } \\
\text { Gijs M. van Gaans }{ }^{1,2}\end{array}$} \\
\hline \multicolumn{2}{|c|}{$\begin{array}{l}\text { Affiliations: } \\
\text { 1Radboud University, the } \\
\text { Netherlands }\end{array}$} \\
\hline \multicolumn{2}{|c|}{$\begin{array}{l}{ }^{2} \text { Research Fellow, } \\
\text { Department of Church } \\
\text { History and Polity, University } \\
\text { of Pretoria, South Africa }\end{array}$} \\
\hline \multicolumn{2}{|c|}{$\begin{array}{l}\text { Note: } \\
\text { Contribution to 'Augustine } \\
\text { and Manichaean } \\
\text { Christianity', the First } \\
\text { South African Symposium } \\
\text { on Augustine of Hippo, } \\
\text { University of Pretoria, 24-26 } \\
\text { April 2012. Drs Gijs M. van } \\
\text { Gaans is participating as } \\
\text { research fellow of Prof. Dr } \\
\text { Hans van Oort, Professor } \\
\text { Extraordinarius, Department } \\
\text { of Church History and Polity } \\
\text { of the Faculty of Theology, } \\
\text { University of Pretoria, } \\
\text { Pretoria, South Africa. }\end{array}$} \\
\hline \multicolumn{2}{|c|}{$\begin{array}{l}\text { Correspondence to: } \\
\text { Gijs van Gaans }\end{array}$} \\
\hline \multicolumn{2}{|c|}{$\begin{array}{l}\text { Email: } \\
\text { gijsmartijnvangaans@gmail. } \\
\text { com }\end{array}$} \\
\hline \multicolumn{2}{|c|}{$\begin{array}{l}\text { Postal address: } \\
\text { Maalderijstraat 21, } 4909 \text { BS, } \\
\text { Oosteind, the Netherlands }\end{array}$} \\
\hline \multicolumn{2}{|c|}{$\begin{array}{l}\text { Dates: } \\
\text { Received: } 11 \text { Jan. } 2013 \\
\text { Accepted: } 11 \text { Jan. } 2013 \\
\text { Published: } 10 \text { Apr. } 2013\end{array}$} \\
\hline \multicolumn{2}{|c|}{$\begin{array}{l}\text { How to cite this article: } \\
\text { Van Gaans, G.M., 2013, 'The } \\
\text { State of Research on the } \\
\text { Manichaean Bishop Faustus', } \\
\text { HTS Teologiese Studies/ } \\
\text { Theological Studies 69(1), } \\
\text { Art. \#1921, } 11 \text { pages. } \\
\text { http://dx.doi.org/10.4102/ } \\
\text { hts.v69i1.1921 }\end{array}$} \\
\hline $\begin{array}{l}\text { Copyright: } \\
\text { (c) 2013. The A } \\
\text { Licensee: AOS } \\
\text { OpenJournals. } \\
\text { is licensed unc } \\
\text { Creative Comn } \\
\text { Attribution Lic }\end{array}$ & $\begin{array}{l}\text { uthors. } \\
\text { IS } \\
\text { This work } \\
\text { ler the } \\
\text { nons } \\
\text { ense. }\end{array}$ \\
\hline \multicolumn{2}{|l|}{ Read online: } \\
\hline 口仿四 & $\begin{array}{l}\text { Scan this QR } \\
\text { code with your } \\
\text { smart phone or } \\
\text { mobile device } \\
\text { to read online. }\end{array}$ \\
\hline
\end{tabular}

According to Augustine's own Confessiones, the Manichaean bishop Faustus of Milevis played a significant role in his apostasy from Manichaeism. Somehow Augustine became disappointed with the intellectual explanations Faustus provided for some of Manichaeism's fabulous doctrines and thereby with Manichaeism as a religion. That same Faustus published a work, the Capitula in which he discussed some exegetical controversies. This work has been preserved, because Augustine cited it in its entirety in his Contra Faustum Manichaeum. In the last hundred years Faustus and his work have received some significant scholarly attention. During that period our view of Manichaeism and subsequently on the Manichaean bishop, has changed. At the beginning Faustus's exegesis was considered merely a form of Manichaean propaganda. Its Christian elements were accepted as a tactic tool in order to covert Catholic Christians to Manichaeism, which was not considered a Christian religion at all. In the course of the 20th century primary Manichaean sources have been discovered. They have enhanced our understanding of the ancient religion immensely. Comparing these texts with Faustus's Capitula reveals that the Manichaean bishop not only defended well-known Manichaean dogmas through his exegesis of scripture, he seems to have contributed to Manichaean exegesis and even Manichaean prophetology. Furthermore, Faustus's Christian, Pauline language can no longer be accepted as a mere tactic adaption to Catholic preferences, but seems to have been his own, genuine language. This article provides an overview of both the research and the debates on bishop Faustus and his works.

\section{Introduction}

During the last century the dry sands of Egypt have proven to be a treasury for ancient history. The arid climate has conserved a number of historical sources from which a large number of fields in ancient history have profited enormously. One of these fields is the study of Manichaeism. It was in Egypt that a significant number of Manichaean texts were recovered.

In 1929 seven papyrus codices were found in the Egyptian oasis of Medinet Madi. They turned out to contain the Kephalaia of the Teacher, Mani's Epistles, the Synaxeis of the Living Gospel, a Manichaean Church history, a book of psalms, a collection of homilies and the Kephalaia of the Wisdom of My Lord Mani. All these texts were composed in Coptic and date from around the middle of the 4th century. Another major source emerged on the Cairo antiques market and was purchased by the University of Cologne in 1969. This so-called Cologne Mani Codex (CMC) was written in Greek and also dates from the 4th century, although a later date has been proposed as well. The text offers written testimonies by some of Mani's disciples on his earlier life and missionary journeys. Besides, from the 1980s onwards excavations in the Dakhleh Oasis - the Roman period village of Kellis - once again in Egypt, recovered papyrological evidence of a Manichaean community there. The Australian-conducted excavation project has unearthed a large number of various sources, amongst which legal documents and personal correspondence written by Manichaean believers (Gardner \& Lieu 2004:35-45).

All these Manichaean sources have increased our insight into the ancient religion of Manichaeism. They also enable us to analyse Manichaean influence on Western religious thought more closely. Until 1929 our most important source on this issue had been the North African church father Augustine (354-430). He had been a well-known auditor of the Manichaean Church for some ten years, before he converted to Nicene Christianity. As a bishop of Hippo Regius (present day Annaba in Algeria), Augustine vehemently defended his Catholic faith against his Manichaean opponents. Because he himself had escaped from the 'devil's snare' of Manichaeism, he must have been considered an appropriate person to disprove the false beliefs of this rival Church. Some opponents, like the Manichaean doctor Felix and the presbyter Fortunatus, he confronted in an open debate. These debates are preserved in two of Augustine's publications Contra Felicem Manichaeum and Acta contra Fortunatum Manichaeum respectively. To others he reacted in writing. For example, he responded to the Roman auditor Secundinus in his Contra Secundinum. 
These debates with Manichaeans have received considerable attention over the last years. A recent book on the topic of 'Augustine and Manichaeism' presented several new contributions on Felix, Fortunatus and Secundinus (BeDuhn 2011:463-480; Hoffman 2011:481-518; Gasparro 2011:519544). These contributors aim to understand not only the course of the debates, but also the main theological positions that were at stake. The same sources that enabled the analysis of Augustine's Manichaean influences, do also allow us to understand the Manichaean background of his opponents.

Of these opponents, the Manichaean bishop Faustus of Milevis deserves closer attention, and for two good reasons. Firstly, Augustine met him whilst still being an auditor of the Manichaean Church in Carthage. The Catholic bishop describes their encounter in a well-known passage of his Confessionum libri XIII 5.6.10-5.7.13. With intense yearning he had awaited Faustus's for meeting him for almost nine years. As an auditor, Augustine had compared Manichaean astrological teachings with those of the philosophers. Because the philosophical writings seemed to offer more plausible explanations of occurrences like solstices and eclipses, he had started doubting Manichaean teachings (Confessionum libri XIII 5.4.6). His fellow believers, however, assured Augustine that Faustus would take away his doubt. But in the end the long-awaited encounter with the Manichaean bishop was a great disappointment. Faustus did not even want to discuss these matters. Furthermore, Augustine found Faustus to be less versed in the liberal arts than he had expected. If this was the best Manichaeism had to offer, there was no use remaining an adherent! Augustine became dissatisfied with the Manichaean faith altogether.

Secondly, the Manichaean bishop deserved special attention, because he published a work entitled Capitula. This work has been preserved in one of Augustine's writings: the very extensive Contra Faustum Manichaeum in 33 books. The work Capitula itself is one of the more extensive writings of Western Manichaeism that is still preserved. Augustine relates that the work fell into the hands of some of his brethren. They asked their bishop to reply to the work, since it spoke against 'correct Christian faith and Catholic truth' (Augustinus, Contra Faustum Manichaeum 1.1). Augustine consented and refuted the work chapter by chapter, first quoting Faustus's text in full. The Capitula thus enables us to considerably complement the image of Faustus that emerges from the Confessiones. The work can also be used to reconstruct the message of a 4 th century Manichaean bishop in a historical context in which the survival of his Church was threatened.

\section{Scholarly debate before the finds of 1929}

\section{Albert Bruckner}

Albert Bruckner was the first person in the 20th century to study Faustus's Capitula (Bruckner 1901). He characterised the work as an instrument of Manichaean (non-Christian) propaganda. Catholic Christian elements present in it were to be interpreted as polemic instruments rather than genuine expressions of Christian convictions. ${ }^{1}$ This premise determined the outlook of Bruckner's work.

\section{Faustus's critique of Catholic exegesis}

Bruckner considered Faustus's critique on Catholic exegesis to be the central theme of the Capitula. This criticism concentrated on two issues. Firstly, Faustus stressed that the Old and the New Testament are completely divergent, something Catholics apparently denied. Faustus deemed this Catholic denial unreasonable (Augustinus, Contra Faustum Manichaeum 8.1). In his view, Jesus' Beatitudes clearly contradict the Law of Moses. Faustus also denied the idea that Jesus' coming had been foretold by the prophets of the Old Testament. The validity of his Christian faith had been sufficiently proven by divine testimony and Jesus' works (Augustinus, Contra Faustum Manichaeum 12.1). Furthermore, Faustus claimed that Jesus had not fulfilled the Law. His works and teachings proved to Faustus that Jesus had in fact abolished the Law. And, although they said otherwise, the Catholics, in his view, rejected the Old Testament as much as Manichaeans did. They clearly refused to follow some of its main commandments, such as circumcision and keeping the Sabbath.

Secondly, Faustus was convinced that Christian scripture was corrupted by Jewish adversaries. He only accepted the New Testament, because its promises of the Kingdom of Heaven and of eternal life are preferable to the earthly and carnal promises of the Old Testament (Augustinus, Contra Faustum Manichaeum 4.1). According to the Manichaean bishop the gospel is nothing more than the preaching and commandments of Christ (Augustinus, Contra Faustum Manichaeum 5.2). But in his view the gospels used by the Catholics contained more than that, since neither Christ, nor his apostles, were their only authors. Later men, using the apostles' names, had inserted new passages. In order to reconstruct the authentic gospel from corrupted scripture, Faustus employed a critical and purely logical exegesis. He only accepted words recurring in a similar context as authentic. Furthermore, those words could only be properly understood when studied together (Bruckner 1901:62).

Faustus rejected all stories concerning Jesus' birth and genealogy and also those passages that seem to support the unity of both Testaments. The scope of this article does not permit us to discuss Faustus's arguments in great detail. However, one argument should receive some particular attention, because it provides a good example of Faustus's exegesis. As will become clear later, this argument concerns a central text in Faustus's polemic, namely Matthew 5:17 ('Do not think that I came to destroy the Law or the Prophets. I did not come to destroy but to fulfil'). Accepting a disparity between the Old and the New Testament, Faustus was logically reluctant to accept this verse. He pointed out that

1.Bruckner saw Manichaeism essentially as a non-Christian religion. He believed Man himself had little contact with Christianity. More than a hundred years later, this view is highly debated. Historians of religion start to view Manichaeism more and more as a Christian current in its own right. 
only Matthew relates these words, but Matthew had not been present himself when Jesus uttered them. At that time Jesus had not even chosen Matthew as one of his disciples. The apostle John was present, but his Gospel does not mention these or similar words. So, Faustus concluded as 'ein gewandter Advokat nach diesem Zeugenverhör', that the authenticity of Matthew 5:17 is doubtful (Bruckner 1901:52).

The Manichaean bishop provided an additional argument. Matthew 9:9 relates the moment when Matthew became an Apostle. It does so using the third person, instead of the first:

And as Jesus passed forth from thence, he saw a man, named Matthew, sitting at the receipt of custom: and he said unto him,

'Follow me'. And he arose, and followed him.

Faustus argues that Matthew had not written the entire Gospel himself. He therefore rejects Matthew 5:17 as genuine words of Jesus (Augustinus, Contra Faustum Manichaeum 17.1) (Bruckner 1901:52-53). Even the Pauline letters did not escape Faustus's exegetical criticism. Bruckner states that he also rejected Romans 1:3, 1 Timothy 4:1-3 and Titus 1:15, for example (Bruckner 1901:60).

\section{Faustus's Manichaeism}

Writing decades before the important discovery of Manichaean texts in 1929, Bruckner's knowledge of Manichaeism was obviously limited. Nevertheless he recognised some distinct Manichaean theological ideas in the Capitula: the myth of the two principles (Augustinus, Contra Faustum Manichaeum 20.2) and a Manichaean belief in the Trinity. In his Trinitarian concept of God, Faustus equated the Almighty Father, the unspeakable light, with the principle of good. The Son Christ is equated with the second, visible Light. The Holy Spirit is believed to have impregnated the earth and thereby brought forth the 'Suffering Jesus' (Iesus Patibilis). According to Bruckner though, this Jesus seems to have been a Fremdkörper in Faustus's theology: he does not seem to have integrated this concept of Jesus into his theology (Bruckner 1901:20-21).

Bruckner argues that Faustus taught a docetic view of the crucifixion. The Manichaean polemist recognised a twofold Jesus: the son of Mary and the Son of God, who were both united at Jesus' baptism (Augustinus, Contra Faustum Manichaeum 12.1). This union was not complete, because the earthly and the heavenly Jesus somehow remained separated. The Son of God clothed himself with the son of Mary and eventually did not suffer on the cross. Faustus understood the passion to be a mystical suffering, not a really corporal one (Bruckner 1901:59-60).

According to Bruckner, Faustus's contribution to Manichaean propaganda had been great. He increased the available polemic material and also established firm critical exegetic principles, whilst using New Testament scripture to support his arguments. His propaganda was aimed at the lack of scriptural knowledge amongst Catholic Christians. This Catholic deficiency contrasted sharply with their faith in scripture (Bibelglauben) (Bruckner 1901:47). Faustus voiced his opinions with great irony and biting sarcasm.
In Bruckner's view then, Faustus is a good example of a wandering Manichaean teacher. He used criticism of the Bible and Catholic exegesis to convince the masses through public debates of the falseness of the Catholic faith. The work Capitula is viewed as an example of propagandist treatises that would have been used by Manichaeans in the absence of such Manichaean teachers.

\section{Paul Monceaux}

In 1926 the French scholar, Paul Monceaux, published his work Le Manichéen Faustus de Milev. Restitution de ses Capitula. Monceaux characterised Faustus's writing as a collection of individual capitula (sing. capitulum = little chapter). The term capitulum referred to a citation from scripture followed by an exegetical analysis of the controversy it addressed. Thus, the Capitula were the controversies of the Manichaean bishop Faustus. $^{2}$ As such the work should be considered polemic. It was written to assist the auditores of the Manichaean Church in defending their faith. The individual capitula provided them with answers to questions Catholic opponents might ask in debates. ${ }^{3}$

Although Monceaux discussed the nature and aim of the work, above all he wanted to reconstruct the original sequence of the individual capitula. According to him, Augustine did not hand them down in Faustus's original order. Consecutive libri of Contra Faustum often discuss controversies that are not related, although some capitula suggest such a relation. For example, in Contra Faustum Manichaeum 32.1 Faustus promised he would examine whether the prophets of the Old Testament had announced Christ. The subsequent book Contra Faustum Manichaeum 33, however does not discuss the issue. Monceaux argued that Augustine had reacted to all the capitula he received and had not altered the sequence himself. He rejected the possibility that later copyists changed the sequence. Somehow the original order got lost before Augustine received the work. In Monceaux's view, the Catholics of Roman Africa had collected all the individual capitula piece by piece. They then transcribed them on a uolumen and delivered that to their bishop as being one book (Monceaux 1926:24).

Monceaux's reconstruction is based on a simple method. First he started by accepting the main themes of the work as mentioned by Augustine in his Retractationes (2.7); critique of the Old Testament, the Law and the prophets, Faustus's view of God of the Old Testament, his view on the Incarnation and his belief that the scriptures of the New Testament had been corrupted. After studying each capitulum individually, Monceaux first seems to have placed them in one of these categories before looking for the best logical sequence within each category. Finally his work provides a reconstructed version of the Capitula in Latin.

2.'Bref, les controverses du Manichéen étaient des Capitula' (Monceaux 1926:17).

3.'Cet ouvrage de Faustus était une sorte de manuel apologétique à l'usage des Manichéens, surtout des laïques' (Monceaux 1926:17-18). 


\section{After 1929}

\section{François Decret}

In 1970 François Decret published his Aspects du Manichéisme dans l'Afrique Romain. Les controverses de Fortunatus, Faustus et Felix avec saint Augustin. Decret studied the nature of North African Manichaeism, by analysing the controversies of Augustine with its well-known spokesmen Fortuntatus, Faustus and Felix.

Like Bruckner and Monceaux, Decret characterises Faustus's Capitula as a 'compendium a l'usage du "parfait polémiste manichéen" pour des favorables' (Decret 1970:61). Faustus started composing this work when he was in exile. ${ }^{4}$ This banishment had involuntarily put his missionary activities on hold. He recorded his main polemic arguments, in order to support similar activities by other Manichaeans. He might have completed and published his work after his release (Decret 1970:61).

Decret deems Monceaux' restitution of the Capitula questionable. For one thing, we are uncertain whether Augustine received all of Faustus's capitula. Yet, like Monceaux, he accepts the main themes as mentioned in the Retractationes. Nevertheless, he distinguishes those capitula that discuss interpolations in the Pauline epistles from those that discuss those interpolations in the Gospels (Decret 1970:66-67).

\section{Manichaean myth in Faustus's Capitula}

Since the discovery in Egypt of Manichaean texts our insight of Manichaean ideas and myths has expanded. Decret compared these ideas with those apparent in Contra Faustum Manichaeum and in the acta of the debates between Augustine on the one hand and Fortunatus and Felix on the other. He concluded Faustus seldom referred explicitly to Manichaean myths. Decret's close reading of Contra Faustum Manichaeum showed these myths definitely formed the backdrop of Faustus's theological thinking. Concerning Faustus's theology two issues should be discussed further: the fundamental Manichaean dualism, and the corresponding concepts of both God and the Devil and his soteriological convictions.

Faustus explicitly distinguished the principle of Darkness from that of Light in Contra Faustum Manichaeum 20.1-4, 21.1 and 25.1. Faustus seems to have felt uneasy with this Manichaean dualism and the underlying concepts of God and evil. The reader gets a glimpse of his concept of God in Contra Faustum Manichaeum 25.1. In the corresponding capitulum Faustus reacted to the Catholic question whether he believes God is limited or not. Manichaeans accepted that the principle of Darkness poses boundaries to the principle of Good. In his defence, Faustus argued that Catholics limit their God as much as Manichaeans do. Rhetorically, he asked if they pray to the 'God of Abraham and the God of Isaac and the God of Jacob?' By accepting the Old Testament in this way, Catholic Christians accept God limits himself to those circumcised like a herder who accepts as his flock only those sheep that are branded with his sign. With this answer he didn't deny dualism and at the same time avoided discussing Manichaean myth at great length.

Faustus referred to the principle of Darkness as hyle (matter; Augustinus, Contra Faustum Manichaeum 21.1). On the nature of hyle he is not outspoken either. He called it 'the demon' (Augustinus, Contra Faustum Manichaeum 21.1), because that's how it is commonly called. It possesses all evil (Augustinus, Contra Faustum Manichaeum 20.1) and limits the expansions of God. When this acceptance of the two principles led to charges of polytheism, Faustus rejected these sharply; Manichaeans only accepted the principle of Good as God (Decret 1970:198-199).

Why did Faustus remain comparatively vague on these issues, especially compared to Felix and Fortunatus? The Catholics labelled Manichaean myth as superstition. Considering Manichaeans stressed their reliance on reason, Faustus might have wanted to avoid this accusation by not discussing the issue in great detail. It is also possible that his rank as a bishop made him more prudent in these matters. Decret, however, provides another hypothesis, one that does not exclude the former two; the Capitula were not acta of an open debate. In such debates skilled opponents, like Augustine, would have forced Faustus to discuss his convictions more thoroughly. They would subsequently have characterised these ideas as incredible fables, thereby disproving the reasonable nature of Manichaeism. Since Faustus probably wrote his work in a less demanding setting, he was able to remain relatively silent on this subject (Decret 1970:244-245).

Decret argues that in Contra Faustum Manichaeum 24.1 Faustus discusses the creation of humankind. With reference to Ephesians 4:22-24 Faustus distinguished between two types of human beings, each with his own birth. The first is the earthly man, whose carnal birth is caused by the forces of Darkness. The second type of man is the 'internal celestial man'. He is created by the forces of Good in a second birth. Faustus views this second birth as a liberation, that 'consiste à nous initier à la foi, dans le Christ Jésus, par l'Esprit-Saint, sous l'enseignement des hommes de bien' (Decret 1970:259).

Faustus's soteriology was clearly Manichaean: salvation meant the liberation of the divine particles from matter and their return to the spiritual realm of the Father. These particles had been dispersed in the material world. In Faustus's work this soteriology was closely connected to his Christology. The Manichaean bishop accepted Jesus as the spiritual Christ - which Decret equates with the Iesus patibilis - who came to bring the message of salvation to those partes dei. He accepted Christ as the Word, the Son of God (Augustinus, Contra Faustum Manichaeum 2.1). He came from the Father alone and had therefore no terrestrial parents. Hence, Faustus could never accept the birth stories in the Gospels (Decret 1970:280). Jesus, in his view had never been born in the flesh, but remained a purely spiritual being. He never became mixed 
with matter, which is the principle of Darkness. Because the Son of God had never been truly born, he could never have actually died. Therefore his suffering could never have been corporal, only mystical (Decret 1970:285).

Mani also played a significant role in Faustus's soteriological thoughts. He is called 'the theologian' (Augustinus, Contra Faustum Manichaeum 20.3) and 'the teacher' (Augustinus, Contra Faustum Manichaeum 19.5). He is considered to be the Paraclete, promised by Christ himself, to reveal the entire Truth (Jn 16:15; Augustinus, Contra Faustum Manichaeum 32.6). ${ }^{5}$ This Truth entailed a consciousness (gnosis) of man's forgotten divine origin. Thus Mani's teachings provoke an anamnessis of this divine nature in all the faithful, thereby bringing about a metanoia that converts.

Salvation lies not in this gnosis alone; man needs to follow moral commandments as well. Faustus considered Jesus' Beatitudes to be both the central message of the Gospel and the fundament of his own ascetic lifestyle (Augustinus, Contra Faustum Manichaeum 5.3) (Decret 1970:286-289). The moral obligations - such as the prohibition of drinking wine and eating meat - are those of the Manichaean Elect. These electi then become the most rigorous followers of Christ's teachings.

\section{Manichaean gnosis}

Eight years later Decret published L'Afrique Manichéene (IV $V^{e} V^{e}$ siècles). Étude historique et doctrinale (Decret 1978), where he studied Faustus's concept of gnosis more closely. Manichaeans juxtaposed their critical stance in religious matters to the blind faith of their Catholic opponents. To prove this stance was justifiably Christian, Faustus referred to the story of the Apostle Thomas. In doubt Thomas was not spurned or simply told to believe, but was given proof of the Resurrection (Jn 20.27; Augustinus, Contra Faustum Manichaeum 16.8). However, in Manichaean thoughts knowledge depended on gnosis, not on discursive and rational thought. Texts like The Fundamental Epistle seem to present this gnosis as the fundamental 'science' on which all true knowledge is based.

Faustus believed that truth is attained by meditation and contemplation, not by 'scientific methods' (Decret 1978:260 289). Take Faustus's doubts about Matthew 5:17 for example. Rational analysis of this locus made Faustus accept only the Jewish Christians as true Christians, because they accepted the entire Law. Catholic Christians did not. Faustus therefore had thought of joining a Jewish-Christian community (Augustinus, Contra Faustum Manichaeum 19.5). The Manichaea fides however taught him that this text had been corrupted (Augustinus, Contra Faustum Manichaeum 18.3). Thus, truth is not attained by rational thinking but through Manichaean fides and gnosis.

In the Contra Faustum Manichaeum 32, 6 Faustus cited John 16:15 as proof for his view on the Paraclete. The Manichaean

5.Although Mani is not mentioned specifically here, Decret (1970:286) believes he is referred to: 'Certes, le nom de Mani n'est pas cite, mais 'le bienheureux père' est clairement désigné par le rôle qu'il a assume.' bishop seems to have used a codex that mentioned the verb inducere to describe the Paraclete's mission. He is said to 'lead you into all truth and he will proclaim to you all things and remind you of them.' The Paraclete would therefore initiate us into gnosis. The verb inducere renders John 16:15 the perfect justification for the initiative character of the Manichaean Church. Faustus furthermore claimed we become disciples into the faith of Christ through the Holy Spirit and through the teachings of wise men (Augustinus, Contra Faustum Manichaeum 24.1). The Latin text uses 'discipulati', which can be translated as 'we become disciples'. Decret however chose to translate it as 'nous sommes initiés' [we are initiated]. In this translation, the Holy Spirit becomes the power that initiates us. Manichaeans would have understood that as an initiation into the gnosis of our divine nature (Decret 1978:272). Faustus saw in Mani the 'grand promoteur de la Gnose'. It was he in his role as the Paraclete that revealed the principles of Good and Evil and our divine origin.

\section{Small contributions between 1978 and 2001}

In the Prosopographie Chrétienne du Bas-Empire André Mandouze and his collaborators provided an overview of the then current consensus on Faustus (Mandouze 1982:390-396). They largely accept the image presented in the Confessiones, but they also acknowledge Faustus's extensive knowledge on both the Old and the New Testament. Furthermore, an interesting episode in Faustus's life is discussed. Faustus probably travelled to Rome in 382/383, where he would have met the Manichaean auditor Constantius. This 'hearer' experimented with a form of communal living in his own house. This experiment failed, because some of the participants were quite lax in following Mani's commandments. Other participants wanted to persevere and create a schism from the Manichaean community. They were called 'Mattarians', since they preferred to sleep on simple mats. Augustine confronted Faustus personally about this episode, attacking the bishop's ascetic lifestyle (Augustinus, Contra Faustum Manichaeum 5.5). The bishop of Hippo argued that Faustus's less than sober lifestyle had not only shunned the Mattatarians, but also his poor family from Milevis. It seems Augustine referred to a personal experience of his Manichaean opponent.

The encyclopedia Augustine through the Ages (Coyle 1999) devoted two separate lemmas on the subject: one on Faustus himself and one on Contra Faustum Manichaeum. Allan D. Fitzgerald's contribution on the bishop is quite short and primarily provides a short biography. On Faustus's religious ideas, Fitzgerald (1999:356) remarks, 'Faustus accepted quae saluti convenienta from the New Testament, but rejected the whole Old Testament.' This view is consistent with Bruckner's: Faustus used the New Testament to sustain his propaganda.

In his contribution on Contra Faustum Manichaeum, J. Kevin Coyle noted that Faustus meant to show that Manichaeism is the purest form of Christianity. Coyle points out that Faustus referred to writings recognised by Catholics, when 
repudiating their religious ideas. He did not use Manichaean works explicitly to support his arguments. Faustus's primary target was the inspired character of the Old Testament. The Capitula is characterised as:

the most extensive Manichaean polemic we possess against what is seen to be the Old Testament's wicked dietary, meaningless ritual requirements, and moral deficiencies, and the fraudulent character of Moses and the prophets. (Coyle 1999:355-356)

In the Augustinus Lexicon, edited by Cornelius Mayer and others, François Decret again discussed both Faustus and Contra Faustum Manichaeum. He still characterised the Capitula as a disputatio on a specific scriptural loci and as an instruction for propaganda. Contrary to what he argued in his Aspects du Manichéisme, Decret here accepts that Augustine refuted all of Faustus's Capitula. Monceaux's reconstruction is still rejected, since there might well have been no original sequence to begin with. The individual capitula were controversies that could have been used separately (Decret 2008:1244-1255). But Decret still largely accepted the themes as proposed by Monceaux. Again, he interprets Faustus's ideas on the concept of God as a defence against the accusation of polytheism. Faustus recognised two principles, deus et hyle. They should however not be understood as two separate deities. Like Good, evil had its own proper substance (Augustinus, Contra Faustum Manichaeum 21.1). It is called 'matter' (hylē) for a reason. In Manichaean thoughts the divine particles were imprisoned in matter. The divine and the material were believed to be mixed. Catholics therefore accused Manichaeans of being materialistic. Faustus responds by arguing that 'we have the same religious attitude regarding all things as you have regarding the bread and the cup' (Augustinus, Contra Faustum Manichaeum 20.2). In his view, the Catholic Eucharist was based on a similar materialism, making Catholic criticism of Manichaean hypocritical (Decret 2008:1248).

\section{Gregor Wurst}

In a more extensive contribution to the debate, Gregor Wurst argued that the term capitula should be understood as a Latin translation of the Greek term kephalaia (2001:307324). This would make a parallel between Faustus's work and the Manichaean Kephalaia plausible. These Kephalaia were a well-known and widely distributed genus litterarium within the Manichaean Church. Because it was such a popular Manichaean genre, the Kephalaia must have been known in North Africa, although there is no proof for that. According to Wurst, the content of both Faustus's Capitula and the Kephalaia support such a parallel. Each capitulum and kephalaion is written according to a similar structure: the teacher - whether it is Faustus (Capitula) or Mani (Kephalaia) - answers a question on theological issues. Both works also accept the practice of a Manichaean instructive lecture as the 'Sitz im Leben' (Wurst 2001:310-311).

But, as Wurst pointed out, both works differ in some respects. Firstly, the Capitula only once mention an actual opponent (Augustinus, Contra Faustum Manichaeum 23.1). In the Kephalaia the questioner, usually one of Mani's followers is often mentioned by name. The names and characteristics of Faustus's opponents remain mostly unmentioned. It is their question that's important, not their personality. Secondly, the Capitula are written in the first person, whilst the Kephalaia in the third. Finally, Kephalaia are often concluded with an acclamation, a doxology, or an expression of gratitude towards the teacher. These are absent from Faustus's Capitula.

The Kephalaia and the Capitula belonged to a popular genre in Late Antiquity, the so-called Queastiones et Responsiones or Erotapokriseis-literature. This genre is characterised by a dialogue in which the questions are only short and the emphasis is on the substantially longer answer. Yet, Wurst argued, the title of Capitula or Kephalaia seems to have been limited to Manichaean literature.

\section{The structure of the Capitula}

Wurst criticises Monceaux's reconstruction. He argues that Monceaux accepted as the main themes of the Capitula, those that Augustine mentioned in the Retractationum libri II. These were only relevant to Augustine and should be welldemarcated subjects of Faustus's work. Because Monceaux's reconstruction departs from these themes, he could only have reconstructed what Augustine had taken to be the structure. That structure is not necessarily that of the original Capitula.

In his Contra Faustum Manichaeum (1.1), Augustine clearly indicated it was Faustus who had composed a uolumen. This 'book' fell into Augustine's hands after which he handed it to his brothers. The Capitula could not have referred to a number of individual disputationes that Augustine had collected (Wurst 2001:313-318). The structure of the Capitula in Contra Faustum Manichaeum should then be understood as that of the Faustus's uolumen.

There are other sound reasons to accept the sequence presented in Contra Faustum Manichaeum. The questions of the capitula of Contra Faustum Manichaeum 2.1-11.1 are asked in the second person singular. Those of Contra Faustum Manichaeum 12.1-17.1 are asked in the second person plural. According to Wurst (2001), these two groups of capitula constitute two distinct units:

Dieses formale Ordnungkcriterium ist zu evident, als daß es sich um einen bloßen Zufall handeln könnte, inbesondere vor dem Hintergrund der restlichen capitula in c. Faust. 20-33, wo die Anfragen des Katholiken sehr unterschiedlich formuliert sind. (p. 320)

The sequence of the capitula of Contra Faustum Manichaeum 2-11 and 12-17 was the sequence of Faustus's Capitula itself. Contrary to Monceaux, Wurst doesn't believe the themes discussed are disparate. In Contra Faustum Manichaeum 2-11 two issues are discussed: the Manichaean reluctance to accept the Old Testament and the denial of the human birth of Christ. These issues are debated from different angles. Contra Faustum Manichaeum 12-17 addresses the problem of whether Christ was foretold in the Old Testament. Wurst concluded that Contra Faustum Manichaeum retained the 
original sequence of Faustus's Capitula. Faustus had not wanted to structure his work logically. The genre of the Erotapokrisies did not expect him to. He only employed a loose and thematic arranging principle, as shown in Contra Faustum Manichaeum 2-11 and 12-17.

\section{Jacob Albert van den Berg}

In his $2009 \mathrm{PhD}$ dissertation, Jacob Albert van den Berg presents another approach to Faustus's ideas and sources. This dissertation focussed on the ideas of Adimantus, as partly described in his Disputationes. Adimantus had been the first major Manichaean missionary to the Roman Empire. After studying both Adimantus's work and the Capitula, Van den Berg recognised some striking connections. Faustus held Adimantus in high regard, characterising him as the 'only person we need to study after our blissful father Manichaeus' (Augustinus, Contra Faustum Manichaeum 1.1). Sixteen of Faustus's 32 capitula include at least one biblical passage already used in the Disputationes. The argument that the Law of Moses contradicts the Gospel of Jesus on circumcision, the Sabbath, sacrifices and dietary laws, is used by both Manichaeans. Also, Augustine explicitly referred to Contra Adimantum in his Contra Faustum Manichaeum (6.6; 16.30). Both references concern Matthew 5:17, which, as we have seen, was an important passage in Faustus's argument. It had apparently been important to Adimantus as well. Van den Berg concluded that Faustus was profoundly involved in a discussion similar to the one Adimantus was involved in when he wrote the Disputationes.

Although Faustus never names Adimantus as a source for particular capitula, he might have used his Disputationes for his arguments against the Old Testament. Van den Berg acknowledged that Faustus lifted Adimantus's arguments from their original context. Nevertheless, Van den Berg uses the Capitula as a possible source for Adimantus's ideas on the New Testament. Works in which Adimantus might have discussed the New Testament are lost, but Van den Berg considers Adimantus such an important source for Fautus, that he argues his approach is valid (Van den Berg 2009:100-106).

To support this approach, Van den Berg quotes Contra Faustum Manichaeum 12.1, where Faustus mentions the books of the 'Manichaean fathers (parentum nostrorum libris).' The exact identity of these fathers is not revealed. By reading this passage in combination with Contra Faustum Manichaeum 1.1, Van den Berg proposed that Adimantus was at least one, if not the only one of the aforementioned fathers. Furthermore, Contra Faustum Manichaeum 22.1-5 and 32.4 discuss the immoral life of the Hebrew prophets. In Contra Faustum Manichaeum 22.5 Faustus recalls the atrocities, mostly sexual in nature, those prophets committed. In Contra Faustum Manichaeum 22.4 the Manichaean bishop reminds his readers that the authors of the Old Testament even dared to publish calamities against God. Similar arguments are found in Titus of Bostra's Contra Manichaeos 3.7. Earlier in the work Van den Berg used a fragment from Photius's Bibliotheca to argue
Titus actually wrote against Adimantus (2009:48). The fact that both Adimantus and Faustus used the same arguments strengthens his hypothesis.

Van den Berg explains the structure of the Capitula from its Sitz im Leben; the individual capitula originated in actual debates with Catholic opponents. Since individual debates would have differed in length, so do the corresponding capitula. At the same time, the same issues might have been debated several times, which explains why some capitula address the same issues from different angles. Faustus's work itself does not contain verbatim reports though. The accounts were polished as to provide more effective instructions for later missionaries. Van den Berg follows Wurst in arguing the Kephalaia served as a stylistic example for Faustus's Capitula. However, he notes, the word Kephalaia should have been translated more correctly as Capita. By using the diminutive term 'Capitula' Faustus might have acknowledged his work was not of a lesser standard than those Kephalaia (Van den Berg 2009:194-196).

\section{Adimantus as Faustus's Paraclete}

To substantiate his approach of using the Capitula as source about Adimantus, Van den Berg discussed Faustus's vision of the Paraclete. Faustus stated Manichaeans were able to discern authentic passages of the New Testament through the guidance of the Paraclete. In Contra Faustum Manichaeum 1.2 Faustus already claimed Adimantus unmasked the deceptions of the semichristiani, which Van den Berg interprets as the faulty Catholic exegesis of the New Testament. Van den Berg then also cites a later Latin formulation of the Renunciation that identifies both Adimantus and Mani as the Manichaean Paraclete (2009:208). Based on this evidence, Van den Berg argues Faustus accepted Adimantus as well as Mani as the Paraclete. It was the Paraclete who enabled a valid exegesis of the New Testament, Faustus seems to have stated that Adimantus had done the same and a later source identifies both Mani and Adimantus as the Paraclete.

\section{Alban Massie}

In 2010 Alban Massie presented his $\mathrm{PhD}$ dissertation, Peuple prohétique et nation témoin. Le peuple juif dans le Contra Faustum de saint Augustin. This dissertation was published by the Institut d'Études Augustiniennes in the following year (Massie 2011). Massie analyses Augustine's thoughts on the Jewish people in Contra Faustum Manichaeum, because these ideas refuted Faustus's thoughts on the subject, that the Capitula are analysed first.

Massie also characterises the Capitula as a collection of controversies (disputationes) on specific scriptural loci and their exegesis. The Capitula were written during a period of severe persecution. During that time, Manichaeans remained well-known for their love of controversies and debate. These allowed them to stress that their religion was based on reason instead of blind faith. Through these disputationes Manichaeans argued that their ideas were based on a sound exegesis. Massie agrees with Wurst that Faustus's work is 
comparable to the Manichaean Kephalaia. He underlines that both the Capitula and the Kephalaia take the form of Quaestiones-Responsiones/Erotapokriseis. This genre is considered to have been an important literary instrument of Manichaean propaganda.

\section{Faustus's Manichaean prophetology}

Massie's thoughts on the main subject of Faustus's work constitute his greatest contribution to the debate. The central theme of the Capitula is Faustus's refutation of the Catholic prophetic argument, an argument that concentrated on the unity of the Old and the New Testament (Massie 2011:70, 185). The Catholics accepted the Old Testament prophets as precursors to Christ, because they had foretold his coming. At the same time Christ confirms this by fulfilling the Law. Jesus' mission was an announced part of the divine plan, which was accomplished through history. This Catholic argumentation rested particularly on their interpretation of Matthew 5:17 and Luke 24:27, 47 (Massie 2011:72).

Faustus rejected both the Old Testament and its prophets, because their particular nature of the Law contradicted Manichaeism's universal pretensions. Yet, as Decret already pointed out, Faustus did not express his thoughts using familiar Manichaean terms. Massie therefore provides a framework of Manichaean prophetology, which differed greatly from that of Catholic Christianity. It does not propose a succession or an evolution of the message of salvation. Instead, this message is believed to be essentially a-historical; it supposes the continuous renewal of the original message brought by Jesus-the-Splendour. Manichaean prophets, called prophets of Light, were all believed to be beneficiaries of this message, which brought forth an illuminatory gnosis. This gnosis entailed at least the discernment of the two principles, their current mixed state - in both this world and the human soul - and the battle of the three times. Thus, the prophets of Truth invoked an anamnessis of the Kingdom of Light. Mani's message was believed to be valid for all time, past, present and future. In that sense his vocation was truly a-historical (Massie 2011:87-94).

According to the Manichaean bishop a true prophet of Truth doesn't need scriptural validation, something which John 10:38 - 'If you don't believe me, believe my works' - seems to underline. His truthfulness is sufficiently proven through his works, that become apparent in his uita honesta, prudentia et uirtus (Augustinus, Contra Faustum Manichaeum 12.1). Jesus' life could be described as such. Faustus referred to Matthew 7:16 - 'You certainly forget that Scripture said that grapes are never harvested from thorns or figs from thistles' - to support his claim. The Old Testament prophets and patriarchs on the other hand had failed to live an honourable, wise and virtuous life. The Old Testament prophets and patriarchs are to be considered fruits of the bad tree, which is the Hebrew God. Yahweh is therefore identified with the principle of Darkness (Massie 2011:110-112).

To stress the importance of a moral life, Faustus used Paul's scheme of the two births as mentioned in Romans 6:6 and
Ephesians 4:22-24 to juxtapose the physical birth with the celestial one (Augustinus, Contra Faustum Manichaeum 24.1). Our first birth is our physical one. Because it encapsulates the particles of Light in matter, it is caused by the forces of Darkness. Manichaean gnosis brought forth by the principle of Light, is the cause of our second, spiritual birth. Referring to Colossians 3:11:

Strip off the old man with his actions, and put on the new, who is being renewed in the knowledge of God in accord with the image of him who created him in you.

Faustus argued this second birth has ethical consequences. The anamnessis of the two principles, their mixed state and our divine origin, makes man follow the ethical standards of the Manichaean electi. Those Manichaean elect thereby become the missionaries of this gnosis, through both their teachings and moral behaviour.

Faustus argued Moses lacked the prudentia of a prophet. In Deuteronomy 21:23 he had cursed Christ by referring to the crucifixion - 'Cursed is everyone who hangs on a tree.' Someone who cursed the Son could never have known the Father. He therefore never showed the prudentia of a true prophet (divinus) (Massie 2011:121-122). In Massie's view this lack is significant, since prudentia was accepted as a cardinal virtue. Of course Faustus saw Jesus as a wise man, as shown in his teachings and predicta.

The uirtutes of Christ are another matter. On the one hand Faustus mentioned Jesus' moral qualities of an honest man. On the other hand, he concentrated on his miracles as examples of his virtues. In Contra Faustum Manichaeum 26.2 he argued these miracles were made possible through the power and might of God. Jesus' miracles, then, were the result of the uirtutes of God (Massie 2011:110).

To distinguish the Hebrew and pagan prophets on the one side from the prophets of Light on the other, Faustus provided a tripartite taxonomy. Departing from Romans 2:14-15 and 8:2 he distinguished three types of law: the Law of the Hebrews, which Paul calls 'the Law of Sin and Death'; the law of the Gentiles, which is identified as the natural law, and the Law of Truth. Subsequently, three types of prophets are distinguished: the Hebrew prophets, the pagan prophets - like the Sybil or Hermes Trismegistos - and the Prophets of Truth (Augustinus, Contra Faustum Manichaeum 19:2; Massie 2011:70-71). Within this taxonomy the Law of Truth is superior, the Law of the Hebrews inferior. In Contra Faustum Manichaeum 12.1, the Hebrew prophets are qualified as uates [seers], a term that also refers to pagan priests.

Faustus accepted as true prophets of Truth, those people who brought the Manichaean gnosis, the discernment of the two principles, their mixture and battle and their unavoidable separation in the end. Faustus provided further criteria to distinguish true from false prophets. Attainment of this salving gnosis results in a uita honesta, prudentia et uirtus. A true prophet can be recognised not only by his teachings, but by his life and works as well. Faustus's Jesus had proven to 
be a prophet of Truth. Not only did he live a moral, wise and virtuous life (Augustinus, Contra Faustum Manichaeum 12.1), his teachings were in accord with Manichaean teachings.

Faustus viewed the Gospel as a short overview of Jesus's message. Christ's euangelium should be accepted as a mandatum, an instruction for conduct. This mandatum is encapsulated in the Beatitudes and differs greatly from the Law of Moses (Augustinus, Contra Faustum Manichaeum 5.1; Massie 2011:128-129). The Hebrew prophets who had followed the Law were not accepted as prophets of Truth. Not only was their life immoral, but their teachings (the Law) were completely disparate from the message of Light as well.

\section{Polemic against Catholic prophetic arguments}

A few loci of the New Testament seem to contradict Faustus's ideas. Faustus criticised Catholic exegesis on these passages. Because it explicitly connects the Law of the Old Testament with Christ's Gospel, Matthew 5:17 was an important locus in the debate. Contrary to the Catholics, Faustus argues that Jesus had in fact fulfilled not the Law of Moses, but that of Light. The capitula of Contra Faustum Manichaeum 17.1-2, 18.1-3 and 19.1 provide arguments to substantiate this idea. Contra Faustum Manichaeum 17.1-2 provides the argument already discussed by Bruckner: the authenticity of Matthew 5:17 is doubtful. In Contra Faustum Manichaeum 18.1-3 Faustus shows that Christ's works indeed contradict the Law (Massie 2011:129).

Another relevant locus was John 5:46 - 'For if you believed Moses, you would believe me; for he wrote about me.' Contra Faustum Manichaeum 16.1-8 discusses this verse. To Faustus, it primarily posed a hermeneutic problem. He starts by stating no prophesies about Christ are to be found in the writings of Moses (Augustinus, Contra Faustum Manichaeum 16.2-3). He cited two verses from Deuteronomy that Catholics apparently used to defend their prophetology: Deuteronomy 18:15 - 'I will raise up for them from among their brothers a prophet like you' - and 28:66 (LXX) - 'They will see their own life hanging and will not believe.' Since these verses don't explicitly name Christ, they should be rejected as proof for the idea that the Old Testament foretells Christ. Again the Manichaean bishop argued that the tradition (traditio) of Moses is very dissimilar from that of Christ. If someone believes in one of them, he would necessarily reject the other.

In his polemic Faustus showed an understanding of Catholic prophetic argument as well as an extensive knowledge of the Old Testament. His critique on both those Old Testament prophets and Catholic Christology are based on scriptural arguments from both Testaments. When he discussed his faith he used a Pauline language. The epistles of the apostle play a significant part in the Capitula (Massie 2011:135-139). Faustus's faith seems to have been based on a clear notion of gnosis described above. In this, Faustus clearly accepts the Pauline discernment of the two births and the two men. Only the second birth in man's initiation is into the truth, since it is the work of the Holy Spirit (Massie 2011:186). His tripartite taxonomy itself is mostly derived from his reading of Paul's letter to the Romans. This language, according to Massie is more than a captatio beneuolentiae, a polemic tool to win over Catholics. It is his own religious language. Paul is an important source for Faustus's Manichaean theology.

\section{Faustus's contribution to Manichaean thoughts}

Faustus's aim - confronting the Jewish superstition - is characteristic for Manichaean polemic. It was the central theme of Adimantus's Disputationes as well. Faustus's thoughts on prophets correspond largely to what is known from other sources. But Massie is convinced that the Capitula is a unique work. It is the only Manichaean source we have on this specific tripartite taxonomy of prophets. This taxonomy might have been one of Faustus's contributions to Manichaean prophetology. Faustus used his extensive knowledge of scripture to support his own ideas and to discredit Catholic arguments.

Faustus's Capitula shows Western Manichaeans employed a prophetic argument of their own. Only the prophets of Light, those who brought the Law of Truth, were to be accepted as true prophets. The prophets of the Hebrews and of the pagans should not. True prophets could be recognised by their message and their moral conduct. This excluded the Jewish prophets, since their life had been amoral. It also unmasked their God, whose promises were carnal. Yahweh should therefore be equated with hyle, the principle of Darkness. Because Catholics did not straightforwardly reject this 'Jewish superstition', Faustus accused them for being mere semichristiani.

\section{Jason David BeDuhn}

How extensive Massie's analysis of Faustus's Capitula may be, his overall view of the Manichaean bishop and his work differs little from earlier authors. He reads the Capitula as polemic work, a guide book for Manichaean polemists to come. Faustus's ideas are believed to be in accordance with those known from (Western) Manichaean texts. In his article 'A religion of deeds: Scepticism in the doctrinal liberal Manichaeism of Faustus and Augustine', American historian of religion Jason David BeDuhn challenges that view (2009:1-28). He elaborates on that subject a year later in his publication Augustine's Manichaean Dilemma 1: Conversion and Apostasy, 373-388 C.E. BeDuhn argues Faustus's Manichaeism was highly sceptical in nature (BeDuhn 2010). The Manichaean bishop adhered to a form of Manichaeism developed by Adimantus. This brand of Manichaeism is thought to have been appropriated to a Western Christian context in two ways: it accepted the Marcionite criticism of the Old Testament and it developed a sceptical rhetoric, derived from the Platonic New Academy.

Philosophers of this New Academy rejected the idea that the true reality could infallibly be discovered. In order not to resort to apraxia - the inability to act - the sage should act on 'discovered probabilities', which meant on evident truth. 
Augustine mentions Faustus had read some works of one of these sceptic philosophers: Cicero (Augustinus, Confessionum libri XIII 5.6.11). Cicero's scepticism was a practice-centred philosophy. He maintained that to prove the truth-likeness of an assumption, one must look at the effects of actions based on it. If an action is successful the underlying assumption is likely to be true, though never certain. Nevertheless it is on these plausible assumptions that man should base his actions.

Since (North African) Manichaeans stressed their reliance on reason, they displayed a great scepticism towards accepting ideas merely based on authority (BeDuhn 2010:2-3). BeDuhn argues that this attitude was an adoption of Manichaeism to the sceptical-dogmatic debate in Hellenistic philosophy. However, Manichaeans usually did not adopt a sincere sceptical position. Rather, they tactically accepted sceptical rhetorical techniques.

BeDuhn believes that, like Cicero, Faustus sceptically subordinated doctrine to practice. In Contra Faustum Manichaeum 32.2 he stated Manichaeans accept from the Gospel only what is useful. The rest is rejected. BeDuhn also recognised Carneades's three principles for determining probable truths in the Capitula: the persuasive, the noncontradicted and the tested. ${ }^{6}$ Faustus deemed the Manichaean dualism persuasive. In the capitulum of Contra Faustum Manichaeum 32.7 he argued that there is no contradiction between Christ's teachings and the myth of those two principles. He also argued that the Manichaean interpretation of Christ's words is correct since it is not contradicted by Christ's works (Augustinus, Contra Faustum Manichaeum 12.1). Finally, the truth of Mani's ideas is confirmed by its ability to sustain a moral life (Augustinus, Contra Faustum Manichaeum 12.1; BeDuhn 2009:9-11).

Faustus criticised the Catholic emphasis on belief over practice as contradicting the practical nature of Christianity. Especially those dogmas that were unrelated in justifying a moral life were suspect: 'Implicit in Faustus's emphasis is the idea that details of doctrine are not as important as a system of practice rooted in a plausible general account of the nature of things' (BeDuhn 2009:4). By rejecting the adherence to unproven beliefs as undeniable truths, he showed himself a sceptic. This position permitted him 'to apply sceptical criticism to his opponent and to maintain a remarkable liberal stance towards his own religion's ideological propositions' (BeDuhn 2010:113).

\section{The Gospel as a mandatum}

As a Manichaean electus, Faustus claimed to be an embodiment of the precepts of the Sermon on the Mount (Contra Faustum Manichaeum 5.1). The moral practice as expressed in the commandments of the Beatitudes is considered to be the core of a Christian life. In the ideas of BeDuhn's sceptical Faustus, this lifestyle became proof of the truth-likeness of his message (BeDuhn 2010:116, 2009:7). Since the life of the Elect is clearly moral, the faith on which it is based is valid. 6.Carneades (214/3-129/8 BC) was an Academic sceptic from Cyrene.
Catholic Christians put too much trust on dogma's that were not able to induce a moral life. Manichaeism, which led to a life corresponding to the Beatitudes, should therefore be seen as the authentic Christianity (BeDuhn 2009:4-8).

Faustus saw the Gospel as a mandatum, a set of instructions for conduct. This view was also put forward by Massie. BeDuhn however interprets this in a sceptical way. Faustus equated the Gospel with Christ's commandments. To follow the Gospel then means to follow these commandments, independent of any metaphysical Christological reflections. Thus, a true religion provided instructions for the construction of a new self, appropriate with the self required for salvation.

With these teachings, BeDuhn (2009) admits that Faustus went well beyond the Manichaean tradition. He adopted sceptical philosophy more thoroughly, not only as a mere rhetorical instrument. As such, Faustus should be considered as:

the missing link between Manichaeism and scepticism that is hinted throughout Augustine's works. Manichaeism is not a sceptical tradition, but Faustus is a sceptical individual, and as an individual had a powerful influence on Augustine against which he later reacted. (p. 9)

That is not to say Faustus adhered to a 'thoroughgoing Academic scepticism.' Rather, 'he offered a complete embodiment of Manichaean principle', but 'both alliances were qualified, and idiosyncratically hybridized, in Faustus' (BeDuhn 2010:126). BeDuhn's view on Faustus's teachings is intriguing, but has yet to receive some consensus.

\section{Johannes van Oort's reaction to BeDuhn's sceptical Faustus}

In his review of BeDuhn's book, Johannes van Oort argues that unambiguous proof for a sceptical Faustus is hard to find (2011:543-567, esp. 558-564). Although in the Confessiones Augustine indeed mentioned that Faustus had read some of Cicero's orations, only some common philosophical influence may be inferred. In Confessionum libri XIII 5.7.13 Augustine related that he read some works together with Faustus. Again, BeDuhn argues, they read works by Cicero. Yet, this is highly speculative. Both in Confessionum libri XIII 5 and in Contra Faustum Manichaeum, Faustus is never explicitly presented as a Manichaean sceptic (Van Oort 2011:559-560).

According to Van Oort, Faustus did not emphasise that religion is all about ethics and praxis. In most of his capitula he did indeed blame the Catholics for not following Christ's commandments meticulously. Yet, his faith was twofold: comprising of both deeds and words (Augustinus, Contra Faustum Manichaeum 5.3; Van Oort 2011:561-562). In some capitula he makes some distinct doctrinal statements, for example on the Manichaean Trinity, on Iesus patibilis and on the two principles, as Decret already demonstrated. Van Oort therefore remarks: 'As far as historical research can establish, Faustus was not the person described by BeDuhn' (2011:563). 


\section{Conclusions}

More than a hundred years of scholarship has enlarged our insight into the Manichaean bishop Faustus and his ideas. Some have met a certain amount of consensus, whilst others remain debated. For example, there is no decisive reason to doubt that the Capitula was written as a Manichaean polemic manual. The work is widely considered to be a literary adaption of actual debates, disputations, held between Faustus en Catholic opponents. Its Christian elements are more and more considered to have derived from Faustus's own Christian, Pauline language instead of being used as a polemic tool.

The Capitula is usually accepted as an example of Erotapokriseisliterature. It has been suggested Faustus based his work on the Manichaean Kephalaia. Monceaux's reconstruction of the original Capitula has been widely rejected. Wurst, for example, accepts the sequence as preserved in Contra Faustum. On the other hand, as belonging to the Erotapokriseis-genre, the Capitula does not need such a structure. There might not have been a designed sequence to begin with. This issue deserves more scholarly attention.

Faustus's knowledge and exegesis of both the Old and the New Testament has been a subject of research for a long time. His extensive knowledge of scripture was used to support a literal and logical exegesis. The Capitula's possible Manichaean sources obviously received more and more attention after the discovery of the several such texts in Egypt. Faustus never mentions Manichaean sources by name, but themes known from them are often recognisable in his theology. Faustus had almost certainly studied Adimantus's Disputationes, since he straightforwardly admits his high esteem for this Manichaean missionary. The way in which he used this Manichaean work, especially compared to other sources, requires more research. Especially Van den Bergs hypothesis - Faustus accepted Adimantus as the Paraclete is intriguing, but somewhat unconvincing.

Scholarly debate on Faustus's sources and his work allows us to reconstruct his Manichaean beliefs. On this issue on the one hand BeDuhn provides us with the interesting hypothesis of a sceptical Faustus. Massie on the other hand reconstructs a thoroughly Manichaean Faustus. In his view Faustus used his extensive knowledge of both the Old and the New Testament to defend his Manichaean prophetology against Catholic attacks. Largely following Decret, Massie encounters Manichaean themes in Faustus's Capitula. According to Massie, Faustus is primarily a representative of Manichaeism, not a sceptic.

Bishop Faustus, his Capitula and foremost his ideas remain intriguing subjects. On some fundamental issues agreement has yet to be achieved. Further research might concentrate on the possible parallels between the Capitula and the Kephalaia and Faustus's understanding and use of scriptural and philosophical sources. That way it might be determined to what extent Faustus's Manichaeism corresponded with what is known from other Manichaean sources and in which way it had been adapted to the religious and philosophical discourse of Roman North Africa.

\section{Acknowledgements Competing interests}

The author declares that he has no financial or personal relationship(s) which may have inappropriately influenced him in writing this article.

\section{References}

Augustinus, 2004, 'Acta contra Fortunatum Manichaeum', in F. Decret \& J. van Oort (eds.), Acta contra Fortunatum Manichaeum, Corpus Fontium Manichaeorum, pp. 14-45, Brepols, Turnhout. (Series Latina vol. 2).

Augustinus, 2006a, 'Contra Felicem Manichaeum', in R. Teske (ed.), The Manichaean Debate, pp. 279-316, New City Press, New York.

Augustinus, 2006b, 'Contra Secundinum', in R. Teske (ed.), The Manichaean Debate, pp. 357-390, New City Press, New York.

Augustinus, 2007a, 'Contra Faustum Manichaeum', in R. Teske (ed.), Answer to Faustus, a Manichean, pp. 69-432, New City Press, New York.

Augustinus, 2007b, 'Retractationum libri II', in R. Teske (ed.), Answer to Faustus, a Manichean, pp. 67-68, New City Press, New York.

Augustinus, 2008, 'Confessionum libri XIII', in H. Chadwick (ed.), Saint Augustine. Confessions. A new translation, pp. 3-305, Oxford University Press, Oxford.

Bruckner, A., 1901, Faustus von Mileve: Ein Beitrag zur Geschichte des Abendländischen Manichäismus, Friedrich Reinhardt, Basel.

BeDuhn, J.D., 2009, 'A religion of deeds: Scepticism in the doctrinally liberal Manichaeism of Faustus and Augustine', in J.D. BeDuhn (ed.), New light on Manichaeism: Papers from the Sixth International Congress on Manichaeism, pp. 1-28, Brill, Leiden. (Nag Hammadi and Manichaean Studies 64).

BeDuhn, J.D., 2010, Augustine's Manichaean dilemma, vol. 1: Conversion and apostasy, 373-388 C.E., University of Pennsylvania Press, Philadelphia.

BeDuhn, J.D., 2011, 'Did Augustine win his debate with Fortunatus?' in J.A. van den Berg, A. Kotzé, T. Nicklas \& M. Scopello (eds.), In search of truth: Augustine, Manichaeism and other Gnosticism: Studies for Johannes van Oort at sixty, pp. 463-480, Brill, Leiden. (Nag Hammadi and Manichaean Studies 74).

Coyle, J.K., 1999, s.v. 'Faustum Manichaeum, Contra', in A.D. Fitzgerald, J. Cavadini, M. Djuth, J.J. O'Donell \& F. van Fleteren (eds.), Augustine through the ages: An Encyclopedia, William B. Eerdmans Publishing Company, Grand Rapids, pp. 355356.

Decret, F., 1970, Aspects du Manichéisme dans l'Afrique Romain. Les controverses de Fortunatus, Faustus et Felix avec saint Augustin, Études Augustiniennes, Paris.

Decret, F., 1978, L'Afrique Manichéene (IVE- V' siècles). Étude historique et doctrinale, Études Augustiniennes, Paris.

Decret, F., 2008, 'Faustus Manichaeus', in C. Mayer (ed.), Augustinus-Lexicon, Schwabe \& Co., Basel, vol. 2, pp. 1244-1255.

Fitzgerald, A.D., 1999, s.v. 'Faustus of Milevis,' in A.D. Fitzgerald, J. Cavadini, M. Djuth, J.J. O'Donell \& F. van Fleteren (eds.), Augustine through the ages: An Encyclopedia, William B. Eerdmans Publishing Company, Grand Rapids, p. 356.

Gardner, I. \& Lieu, S.N.C., 2004, Manichaean texts from the Roman Empire, Cambridge University Press, Cambridge. http://dx.doi.org/10.1017/СBO9780511616891

Gasparro, G.S., 2011, 'The disputation with Felix: Themes and modalities of Augustine's polemic', in J.A. van den Berg, A. Kotzé, T. Nicklas \& M. Scopello (eds.), In search of truth: Augustine, Manichaeism and other Gnosticism: Studies for Johannes van Oort at sixty, pp. 519-544, Brill, Leiden. (Nag Hammadi and Manichaean Studies 74). http://dx.doi.org/10.1163/ej.9789004189973.i-730.117

Hoffman, A., 2011, 'Secundinus in der Diskussion mit Augustinus über das malum: Beobachtungen zu den augustinischen Quellen der Epistula Secundini' in J.A. van den Berg, A. Kotzé, T. Nicklas \& M. Scopello (eds.), In search of truth: Augustine, Manichaeism and other Gnosticism: Studies for Johannes van Oort at sixty, pp. Manichaeism and other Gnosticism: Studies for Johannes van Oort at sixty, pp. 481-518, Brill, Leiden. (Nag Hammadi and Man
org/10.1163/ej.9789004189973.i-730.112.

Massie, A., 2011, Peuple prophétique et nation témoin. Le peuple juif dans le Contra Faustum manichaeum de saint Augustin, Institut d'Études Augustiniennes, Paris.

Mandouze, A. (ed.), 1982, Prosopograhpie Chrétienne du Bas-Empire, vol. 1: Prosopographie De L'Afrique Chrétienne (303-533), Éditions du Centre National Prosopographie De LAfrique Chrétien
de la Recherche Scientifique, Paris.

Monceaux, P., 1926, Le Manichéen Faustus de Milev. Restitution de ses Capitula Imprimerie nationale, Paris.

Tardieu, M., 1997, Le Manichéïsme, 2nd rev. edn., PUF, Paris.

Van den Berg, J.A., 2009, Biblical argument in Manichaean missionary practice: The case of Adimantus and Augustine, Brill, Leiden.

Van Oort, J., 2011, 'Augustine's Manichaean dilemma in context', Vigiliae Christianae 65, 543-567. http://dx.doi.org/10.1163/157007211X591830

Wurst, G., 2001, 'Bemerkungen zu Struktur und genus litterarium der Capitula des Faustus de Mileve', in J. van Oort, O. Wermelinger \& G. Wurst (eds.), Augustine and Manichaeism in the Latin West: Proceedings of the Fribourg-Utrecht Symposium of the International Symposium Association of Manichaean Studies (IAMS), pp. 307-324, Brill, Leiden. 